\section{Turn-taking in the Classroom Session in the Movie Freedom Writers by Richard La Gravanese (2007)}

\author{
1 Wahyu Aji Pradana \\ 2 Malikatul Laila
}

12 Universitas Muhammadiyah Surakarta, Indonesia

\section{Abstract}

Speaker $(\mathrm{S})$ and next speaker or hearer $(\mathrm{H})$ requires a turn-taking process in order to obtain the desired information. This study aims (1) to determine the rules of turn-taking used by $\mathrm{S}$ and $\mathrm{H}$ in Classroom sessions in the film "Freedom Writers" and (2) to explain the intention of turn-taking in the Classroom session done in the film "Freedom Writers". The data of this study were the utterances and action which were taken from activities during the class session in the film "Freedom Writers" by Richard La Gravanese (2007). To analyze the data, the researcher refers to Sacks, Schegloff, \& Jefferson's (1974) theory about turn-taking rules. The researcher determines the intention by referring Cutting's theory about pragmatics such as context and conversation analysis. The result of study shows that (1) turntaking $1 \mathrm{~A}$ ( $\mathrm{S}$ chooses $\mathrm{H}$ in the speech) is the highest, (2) turntaking $1 \mathrm{~B}(\mathrm{H}$ is not chosen by $\mathrm{S})$ is the second higher; and turntaking $1 \mathrm{C}$ ( $\mathrm{S}$ can stop or continue speaking) is the least in frequencies. It can be concluded that the rule $1 \mathrm{~A}$ is dominant and is often used in turn-taking in classroom session. (2) The researcher found that the intention within the turn taking are ranged from the highest to the lowest respectively : to ask, to clarify, to demand, to inform, to assert, to support, to request, to invite, to threat, to challenge, and to tease. Therefore, it can be concluded that the intention to ask is the most intention used in classroom session.

\section{Keywords}

conversation analysis

intention

turn-taking

\section{Ethical Lingua}

Vol. 7, No. 2, 2020

ISSN 2355-3448 (Print)

ISSN 2540-9190 (Online)

Corresponding Email

Wahyu Aji Pradana

a320160173@student.ums.ac

.id

Article's History

Submitted 23 Sept. 2020

Revised 7 October 2020

Accepted 7 October 2020

\section{DOI}

10.30605/25409190.217

Copyright (๑) 2020

The Author(s)

This article is licensed under CC BY-NC-SA 4.0 License 


\section{Turn-taking in the Classroom Session in the Movie Freedom Writers by Richard La Gravanese (2007)}

Turn-taking is a rule where there is a change of speech between speaker (S) and next speaker $(\mathrm{H})$ when having a conversation. Schegloff (2007) said that in the process of discussion of turn-taking is how the speaker takes the right to speak next and how the rules of turn-taking in conversation.

Based on some of these objectives, this turn-taking study is very compelling where $S$ interacts leading to the next speaker $(\mathrm{H})$, the next speaker $(\mathrm{H})$ has the right to respond and structurally provide information for speaker (S). The turn-taking process is known as a verbal and logical process, the main objective is to obtain information (Coulthard \& Brazil, 2013). The daily conversation process has rules for creating effective communication.

But in the rules of the turn-taking process, anyone can get a turn to speak based on the opportunity given by the speaker ( $S$ ) in a discussion. Therefore, the importance of the process of turn-taking needs to be studied especially in the process of conversation in the class in the film Freedom Writers.

Turn-taking studies lead to a gender perspective, especially for the field of sociolinguistics by Ghilzai \& Baloch (2015). Butterfield (2015) conducted an analysis with an analytical perspective for language use at a university in Japan. Muryantina (2017) reviewed the results of the interrogation process conducted by the police between the defendant and the victim. Anggraini, (2017) who also reviewed TV talk shows about the controversy of Basuki Tjahaja Poernama, and other similar research was also conducted by Meiristiani \& Ekawati (2018) about the process of conversation in Mathematics courses between teachers and students.

Laila (2018) who investigated speech strategies and initiation in the ILC (Indonesia Lawyer Club). Then the last study has done by Laila \& Puspitasari (2019) that conducted research on the study of turn-taking in ILC that had become the reference and comparison in this research.

This study aims (1) to determine the rules of turn-taking used by $\mathrm{S}$ and $\mathrm{H}$ in Classroom sessions in the film "Freedom Writers" and (2) to explain the intention of turn-taking in the Classroom session done in the film "Freedom Writers". This paper gives the specific rules of turn-taking types and its intentions to find out where the conversation is going especially in classroom discussion which there are so many students as participant and a teacher as moderator manages the discussions effectively.

\section{Method}

This research was in the domain of qualitative descriptive research using the Conversation Analysis or CA approach. With CA studies, the researchers looked at the use of dialogical languages, especially for the two camps of participants, namely moderators and audiences.

The data were taken from the teacher and students who were in the discussion that showed the conversation in the Freedom Writers Movie. The technique of collecting the data were 
recording live discussions in a classroom, which were listening and recording conversations in the Freedom Writers Movie and transcribing the conversation or tapping technique (Sudaryanto., 1993). The technique of data analysis was done using a descriptive method by Sack's theory of turn-taking and Austin's theory of speech act (Austin, 1962).

\section{Results}

\section{Turn-taking}

The result of turn-taking in classroom session are presented in Figure 1. According to theory of Sacks, Schegloff, \& Jefferson (1974), the rule is divided into three types namely S (who is talking) chooses $\mathrm{H}$ (next Speaker) in the speech or the rule of $1 \mathrm{~A}, \mathrm{H}$ is not chosen by (speaker) $\mathrm{S}$, then there is the first right of (next speaker) $\mathrm{H}$ to talk to get the next turn, and $\mathrm{S}$ does not choose (next speaker) $\mathrm{H}$ or the rule of $1 \mathrm{~B}$, and there is no other participant who wants to take a turn to talk (as in b), then $\mathrm{S}$ can stop or continue speaking or the rule of $1 \mathrm{C}$.

\section{Turn-taking}

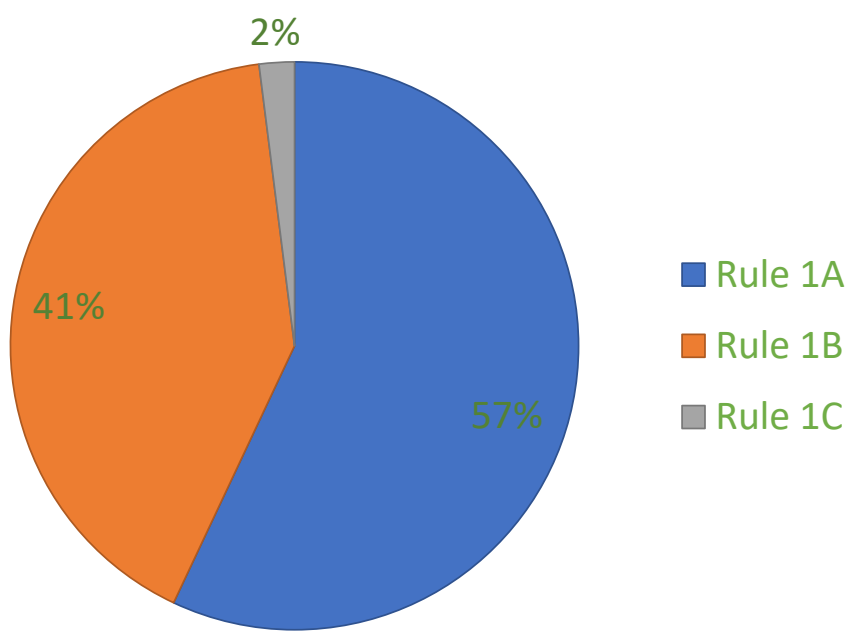

Figure 1. Chart of Turn-taking in classroom discussion

According to data of findings, the researcher conclude that the rule of $1 \mathrm{~A}$ is dominant in classroom session because as a teacher has a right to select who will take a floor next and the teacher will convey what will be discussed in accordance with the intent and context.

\section{Intentions}

The researcher found 11 intentions inside the unit of analysis. The intention is divided into $26 \%$ (to ask); $15 \%$ (to clarify); $12 \%$ (to demand); $7 \%$ (to inform); $7 \%$ (to assert); $7 \%$ (to support); $7 \%$ (to request); $7 \%$ (to invite); $4 \%$ (to threat); $4 \%$ (to challenge); and $4 \%$ (to tease).According to data of findings, the researcher conclude that the intention to ask is the most often used in classroom session.

The result of intentions in classroom session are presented in Figure 2. 


\section{The Intentions}
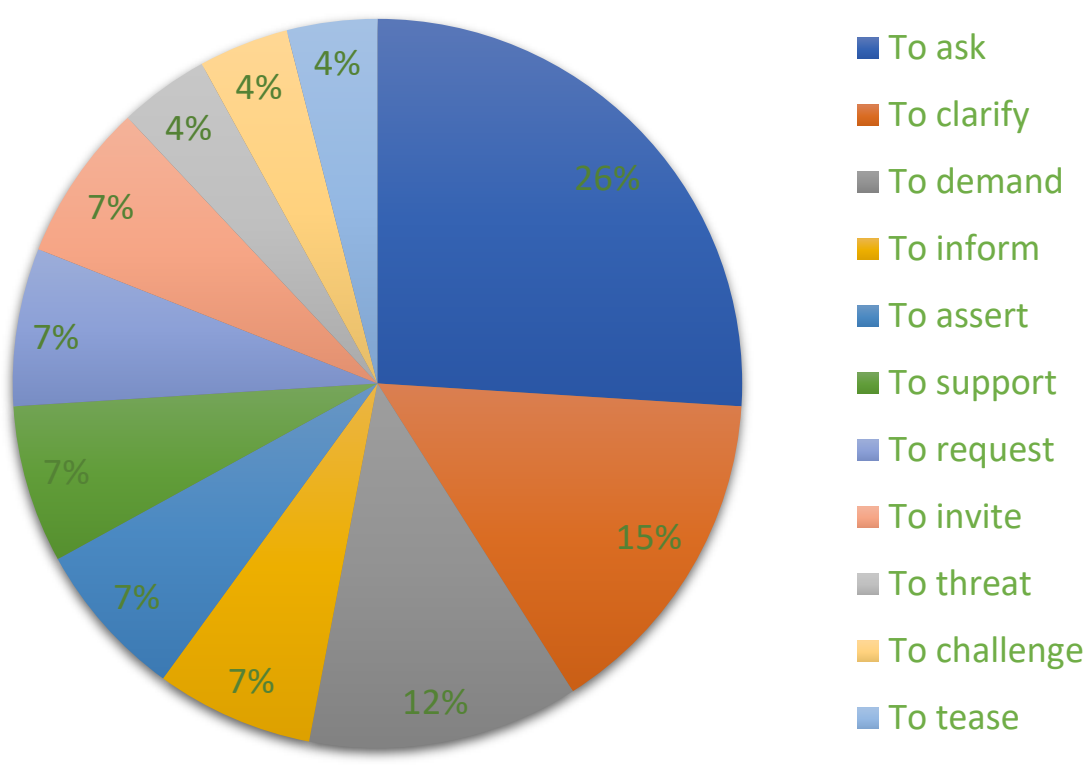

Figure 2. Chart of Intentions in classroom discussion

\section{Discussion}

The researcher provides some discussions related to the finding. This research was conducted based on two research questions. The first is to find out the rules of turn-taking that exist in class discussions by referring to the theory of Sacks and integrally continuing by looking for the intentions of turn-taking in the class by referring to the Cutting's theory. This research is strengthened and compared by several previous studies from year to year by the researcher. There is a lot of discovery in the form of turn-taking and the discovery about interruption has relation with overlap.

The first research has conducted is Ghilzai \& Baloch (2015) which discusses the turn to speak with a gender perspective in the field of sociolinguistics. This study has the result that women are likely to take floor in conversation based on the position of women's gender. This study intends to provide empirical evidence regarding stereotypes and assumptions that have been made by previous researchers. Previous research has shown that women have a greater curiosity, while men prefer to be in their position, stay silent, and refuse to speak. This reinforces the assumption that women speak more than men.

The second research has conducted by Butterfield (2015) who analyzes interactions in the use of language at a university (in Japan) with a perspective analytical conversation. This study found the distinction of pattern that the native English lecturer is undertaking the initiation and provision, and non-native English lecturer provided feedbacks.

The third research has conducted by Muryantina (2017) who analyzed the results of police interrogation between victims and accused by revealing the patterns of allocation of policeman is self-selected. The pattern of allocation of speech turn between the defendant and the victim has been dominated by the police as the initiator (current speaker). The main thing about the 
interrogation talks is that the victim has more power than the defendant while the party with the highest power is the police.

The fourth research has conducted by Anggraini (2017) on the talk show that presented the Ahok controversy. The problem that must be answered through this research is: which part of the speech system occurs in the conversations of Andy and Ahok on the Kick Andy talk show on Metro TV. The study reveals that the four components of the speech system which include speech components, allocation allocations, speech rules, and overlaps, occur as data.

The fifth research has conducted by Earnshaw (2017) about face-to-face conversations in the Online Synchronous Course. By using a conversation analysis approach, the researcher aims to find out the pattern of turn-taking strategies and repair circuits. The results show that several different strategies are used to refine the speaker's turn. If the speech cannot be smooth, the speaker tries to correct it by solving the problem or allowing it. This research shows that chat can be studied on the basis of discussion; online synchronous lectures are used to identify technical difficulties when speakers are called to solve problems.

The sixth research has conducted by Meiristiani \& Ekawati (2018) about conversations between teachers and students in private Mathematics courses. The results show that the turn of speech conducted by teachers and students in private Mathematics courses is generally in the form of question and answer using single words or single phrases. The allocation of speech turns can also be identified by the pause and intonation, as well as the overlap of speech that occurs during the conversation.

The seventh research has conducted by Laila (2018) that shows the strategy of moderator in seeking information from participants by revealing the variation like addressing the addressee verbally and non-verbally, appointing the participants by special surname to respect to them, repeating call by addressing the addressee to get response, and countering opinion of participants.

The eighth research has conducted by Laila \& Puspitasari (2019) conducted turn-taking research about strategies of turn-taking for getting information in Indonesia Lawyers Club Discussion debate in TV One. This research is a reference to be a complement of turn-taking on classroom session research.

Meanwhile, what is done by Sacks, Schegloff, \& Jefferson (1974) is that the mechanism of turn-taking as the basic unit of conversation is the basis of the analysis in this study. Furthermore, research conducted by Sacks, Schegloff, \& Jefferson (1974), Coulthard \& Brazil (2013) was used to support the analysis of turn to speak in the context of comprehensive language use.

Based on those previous studies, there are many similarities and the differences. The similarities are the same theory of turn-taking (Muryantina, 2017; Anggraini, 2017; \& Laila, 2018). And then, the differences are the data analysis and the focus of the research.this research can be classified into valid research that has related researches in the sub part of theories. The rule of $1 \mathrm{~A}$ is often used by teacher as Speaker to get reactions from students as Next Speaker and the intention to ask is very often used to get response. 


\section{Conclusion}

To answer research question, the researcher conclude that the conclusion is related to the theory of Sacks about turn-taking and Cutting about to find intention of speech in classroom session in the film "Freedom Writers".

The researcher shows three rules of turn-taking in classroom session based on Table 1. The unit of analysis shows (1) turn-taking $1 \mathrm{~A}\{\mathrm{~S}$ (who is talking) chooses NP (next Speaker) in the speech\} 57\%; (2) Turn-taking 1B \{NP (next Speaker) is not chosen by S (speaker)\} 41\%; and Turn-taking $1 \mathrm{C}\{\mathrm{S}$ can stop or continue speaking $\} 2 \%$. Therefore, it can be concluded that the rule $1 \mathrm{~A}$ is dominant and often used in turn-taking in classroom session.

The researcher shows eleven intentions of speech in classroom session based on Table 4.2. The researcher divide the intention into to ask $26 \%$; to clarify $15 \%$; to demand $12 \%$; to inform $7 \%$; to assert $7 \%$; to support $7 \%$; to request $7 \%$; to invite $7 \%$; to threat $4 \%$; to challenge $4 \%$; and to tease $4 \%$. Therefore, it can be concluded that the intention to ask is the most intention used in classroom session.

\section{Acknowledgment}

We would like to thank to the official of Department of English Education for the support and encouragement. This article was conducted for Muhammadiyah University of Surakarta.

\section{References}

Anggraini, T. (2017). Study On Turn-Taking Found In Kick Andy Talk Show Of Kontroversi Ahok Episode. Bachelor Thesis. Universitas Brawijaya.

Austin, J. L. (1962). How to Do Things with Words: Second Edition. Oxford: Clarendon Press.

Butterfield, L. J. (2015). Turn-Taking in Conversations for Language Learning.

Coulthard, M., \& Brazil, D. (2013). Exchange Structure. In Advances In Spoken Discourse Analysis. New York: Routledge.

Earnshaw, Y. (2017). Navigating Turn-Taking and Conversational Repair in an Online Synchronous Course. Online Learning Journal, 21(4). Retrieved July 12, 2020 from https://www.learntechlib.org/p/183766/.

Ghilzai, S. A., \& Baloch, M. (2015). Conversational Analysis of Turn taking Behavior and Gender Differences in Multimodal Conversation. Journal of Language Studies, 25(4), 113.

Laila, M., \& Puspitasari, F. D. (2019). The Study of Turn Taking in ILC Discussion. Proceeding of The 2nd ICoLLiT (International Conference on Language, Literature and Teaching) 2019.

Laila, M. (2018). The Study of Sub-Genre Initiation in Indonesia Lawyers Club Discussion. In Fourth Prasasti International Seminar on Linguistics (Prasasti 2018). Atlantis Press.

Meiristiani, N., \& Ekawati, Y. N. (2018). Needs Analysis Of Mechanical Engineering Students In Learning English For Specific Purposes. Research and Innovation in Language Learning, 1(3), 153-166.

Muryantina, R. (2017). Power Relations In The Turn-Taking Of Interrogation Recorded By Net's 86. JURNAL Al-AZHAR INDONESIA SERI HUMANIORA, 3(4), 342-345.

Sacks, H., Schegloff, E.A., \& Jefferson, G. (1974). A simplest systematics for the organization of turn-taking in conversation. Language, 50, 696-735. 
Schegloff, E. A. (2007). Sequence organization in interaction. Cambridge: Cambridge University Press.

Sudaryanto. (1993). Metode dan aneka teknik analisis bahasa. Yogyakarta: Duta Wacana University Press. 